\title{
Como Lidar com Safenas Insuficientes
}

Merlo I. ${ }^{1}$

${ }^{1}$ Rio de Janeiro - Brasil.

E-mail: ivanesio.merlo@terra.com.br

Merlo, I. 2013. Como Lidar com Safenas Insuficientes, p.36. In: Bastos, Francisco Reis. Anais do V Simpósio Internacional de Flebologia [Blucher Medical Proceedings n.1 v.1]. São Paulo: Blucher, 2014

http://dx.doi.org/10.5151/medpro-flebo-SIF_17
Até a introdução do EcocolorDoppler no arsenal de equipamentos para o diagnostico e tratamento das varizes dos membros inferiores, cirurgia de varizes era igual a safenectomia. Podia se ver estampado, no programa de todo centro cirúrgico onde se praticava tal procedimento, o termo safenectomia, onde hoje se vê escrito, cirurgia de varizes.

Algum tempo depois a veia safena magna ou parva passou a ser considerada como um ser vivo raro em extinção e que precisava ser preservado a todo o custo. Dezenas de técnicas foram propostas e descritas para salvá-las de seus "exterminadores". Nessa época surgiu uma nova designação para alguns cirurgiões que ousavam dizer, em suas apresentações científicas, que ainda faziam safenectomias. Esses foram também conhecidos pela alcunha de: "assassinos de safenas".

Os equipamentos e os conceitos diagnósticos evoluíram, os materiais e as técnicas cirúrgicas também se modificaram, em obediência as exigências e as expectativas naturais dos pacientes e dos novos tempos.

Em conclusão, vamos tentar demonstrar que as veias safenas são muito importantes e até imprescindíveis para alguns pacientes, dispensáveis para outros e às vezes maléficas para aqueles cujas safenas dilatadas e com refluxos patológicos, determinam ou estão totalmente envolvidas na doença varicosa. Palavras-chave: varizes, veia safena, IVC, cirurgia de varizes. 